\title{
Management of Mycotoxin in Post-Harvest Food Chain of Durable Crops
}

\author{
Lelise Tilahun Dufera \\ Department of Post-Harvest Management, Jimma University, P.O.Box 307, Jimma, Ethiopia \\ Correspondence: Lelise Tilahun Dufera, Jimma University College of Agriculture and Veterinary Medicine, \\ Jimma, Ethiopia
}

\begin{abstract}
Fungal secondary metabolites (mycotoxins) produced as contaminants on food and feed commodities are considered to be economically and toxicologically important worldwide. Aflatoxins, orchratoxins, fumonisins, zearalenone and trichothecenes are important mycotoxins which have been analyzed as natural contaminants in various agricultural commodities. In this review to minimize the risk of mycotoxin contamination in post-harvest food chain of durable crops; different Post harvest strategies for managing mycotoxins (early harvesting, proper drying, storage management, sorting and detoxification) have been discussed.
\end{abstract}

Keywords: mycotoxin, Fungi, drying, durable crops

DOI: $10.7176 /$ FSQM/100-03

Publication date:August $31^{\text {st }} 2020$

\section{Introduction}

Mycotoxins are secondary fungal metabolites that contaminate agricultural commodities and can cause sickness or death in humans and animals (Choudhary and Kumari, 2010). The term mycotoxine generally only refers to those toxins which are injurious to animals (Reyneri, 2006). It was only in the 1960s, however, that unexplained epidemics in livestock brought research focus on to fungi and certain chemical products of their metabolic processes. Quick to accumulate in food and feed and difficult to remove, these so-called mycotoxins have become a leading concern in food safety, even as researchers continue to discover new types, risk factors, and health impacts (SP-IPM, 2009).Such toxins can be found in several food and animal feeds; maize, wheat and other cereal grains are among the most contaminated commodities (Anonymous, 2003).

The major classes of mycotoxins are aflatoxins, trichothecenes, fumonisins, zearalenone, ochratoxin A, and ergot alkaloids (Anonymous, 2003). The most mycotoxins of concern are produced by three genera of fungi, namely, Aspergillus, Penicillium, and Fusarium. Fungal growth and the production of mycotoxins are greatly influenced by temperature, and water activity (Esteban et al., 2004; FAO, 2007).

Although there are geographic and climatic differences in the production and occurrence of mycotoxins, exposure to these substances is worldwide (Kuiper-Goodman, 2004 cited in Binder, 2007, p.150).And their problems are not specific to the developed or developing world; these are problems that affect the agricultural economies of many countries, interfere or even prevent trade, reduce animal and animal product production and in some countries affect human health (Miller, 1995).

Although the prevention of mycotoxin contamination in the field is the main goal of the agricultural and food industries, the contamination of various commodities with Aspergillus or Penicillium isolates and their mycotoxins is unavoidable under certain environmental conditions (Varga et al., 2010). Post-harvest contamination by mycotoxigenic fungi usually occurs during storage and transportation and is normally caused by improper drying or re-wetting of the crop from condensation or rain (IFST, 2009).

Postharvest strategies aim at lowering fungal contamination and consequently, the mycotoxin content of agricultural products during storage, handling, processing, and transport (Varga et al., 2010). Post harvest control measures include physical methods e.g. improved storage conditions, transportation, sorting and chemical methods such as ammoniation. Correct drying of seeds followed by efficient storage and monitoring is an effective postharvest management technique to prevent mould growth.

\section{Literature review}

\subsection{Mycotoxin in durable crops}

Mycotoxins are low molecular weight toxic compounds produced by certain toxigenic strains of a variety of filamentous fungi under favorable conditions (such as temperature and moisture) and all over the world, they cause enormous economic losses annually to the grain and oil seed trade and marketing (Cardwell et al.,2001). They are produced by certain fungi (e.g., Aspergillus ssp., Penicillium ssp., and Fusarium ssp.) that grow on human food and animal feed ingredients such as corn, sorghum, wheat, barley, peanuts, and other legumes and oilseeds (Dohlman, 2003).

Mould growth and mycotoxin production in grains and oil seeds are very important to producers, processors and consumers of such commodities (Anonymous, 2003). Prior to harvest, grains and oil seeds are protected greatly 
from mould infection by their hard shells. However, endosperm may be attacked by mould if the shells are dented or damaged before harvest. Following harvest, the defense mechanism of grains and oil seeds against fungal invasion decreases (Annor et al., 2004 cited in Negedu etal.,2010,p.37) and there fore, fungal population may increase and subsequently result in the production of secondary metabolites (mycotoxins)during drying, processing and storage (Hell et al.,2009).

A list of mycotoxins significantly impacting agricultural commodities would include aflatoxin produced by A.flavus, and A.parasiticus, zearalenone and trichothecenes (particularly deoxynivalenol) produced by Fusarium spp., ochratoxin produced by A.ochraceus and fumonisins produced by F.moniliforme. (Choudhary and Kumari, 2010). Common mycotoxins found in durable crops are summarized in table 1.

Mycotoxins in Africa are mainly aflatoxin, ochratoxin A, fumonisins, deoxynivalenol and zearalenone(Majiwa et al(eds.),2007)

Table 1: Common mycotoxins found in durable crops

\begin{tabular}{|l|l|l|}
\hline Mycotoxin & & \\
\hline & & \\
\hline & & wheat, barley, oats, and maize \\
\hline & & \\
\hline & & \\
\hline
\end{tabular}

Adapted from:Okello et al., 2010 ;Anonymous,2003; Majiwa et al(eds.),2007.

Aflatoxin

Aflatoxins are secondary metabolites primarily produced by the fungi Aspergillus flavus and A. parasiticus and to a lesser extent A. nomius (Anonymous, 2003). Aflatoxin is one of the most important mycotoxins and is found mainly in groundnuts, edible nuts, oilseeds and cereals (Majiwa, et al (eds.), 2007). Aflatoxins are extremely potent carcinogenic and mutagenic substances which first came into the public spotlight - and were formally identifiedin the early 1960s following the deaths of more than 100,000 young turkeys on a poultry farm in England(Dohlman, 2003).

\section{Fumonisins}

The fumonisins are a group of mycotoxins produced primarily by Fusarium verticillioides and Fusarium proliferatum(Schmale and Munkvold, 2011). The fumonisins occur primarily in maize and are almost-universal pathogen of maize. These toxins are capable of causing significant disease in horses and swine (Anonymous, 2003). Fumonisins are carcinogenic to laboratory animals, and in humans, consumption of fumonisin-contaminated maize is associated with higher rates of esophageal cancer and neural tube birth defects (Schmale and Munkvold, 2011). Ochratoxin A

Ochratoxins are mycotoxins produced by several species of Aspergillus and Penicillium. Ochratoxin A is the most economically important form of ochratoxin (Schmale and Munkvold, 2011).Ochratoxin A is produced by the fungi species called Penicillium verrucosum and Aspergillus ochraceus(FAO,2001).It occurs mainly in cereals, grapes, coffee and wine (Majiwa et al(eds.),2007). It is produced within the temperature range 15 - 37 oC, with an optimal production at 25 - $28 \mathrm{oC}(\mathrm{FAO} / \mathrm{IAEA}, 2001)$ by Penicillium verrucosum and cause significant disease in animals, especially swine:(Anonymous,2003). It is also associated with renal diseases and urinary tract cancers in humans (Majiwa et al (eds.), 2007).

Deoxynivalenol(DON)

Deoxynivalenol (DON) is a natural-occurring mycotoxin mainly produced by Fusarium graminearum (Kushiro, 2008 cited in Sobrova et al., 2010, p.94). DON is probably the best known and most common contaminant of grains and their subsequent products ( Sobrova et al.,2010). DON is sometimes called vomitoxin because of its deleterious effects on the digestive system of monogastric animals. Humans consuming flour made from wheat contaminated with DON often demonstrate symptoms of nausea, fever, headaches, and vomiting(Schmale and Munkvold, 2011).

Zearalenone

Zearalenone is produced primarily by F. graminearum and causes estrogenic responses in swine. It also may cooccur with DON in grains such as wheat, barley, oats, and maize (Anonymous, 2003). Zearalenone contamination is economically important in maize. High humidity and low temperatures favor the production of zearalenone by F. graminearum in maize (Schmale and Munkvold, 2011).

\subsection{Major Mycotoxin Producing Fungi}

Throughout the history of agriculture, the concentrated energy stores of crops have provided ready hosts for molds and other tiny fungal organisms, some of which produce toxins (SP-IPM, 2009).

Toxigenic fungi differ in their capacity to function under different ecological conditions. These are traditionally divided into "field fungi" if they are aggressive as plant pathogens that can cause plant disease, and "storage fungi" that can proliferate and cause infection during grain conservation (Reyneri, 200). The first group 
requires grain moisture above $20 \%$ in cereals and often causes ear rot diseases and toxin production before harvest, when the crop is still in the field. The important genera of field fungi include Fusarium, Cladosporium and Alternaria. The storage fungi usually grow in grain with moisture content in equilibrium with $70-90 \%$ relative humidity, which corresponds to less than $18 \%$ moisture content in cereals, and the most important genera are Aspergillus and Penicillium( Bankole and Adebanjo ,2003). Moulds and mycotoxins of world-wide importance are listed in( table 2).Fusarium, Aspergillus, and Penicillium are the most abundant moulds that produce these mycotoxins and contaminate human foods and animal feeds through fungal growth prior to and during harvest, or during (improper) storage (Bhatnagar et al., 2004 cited in Binder, 2007, p.150).

Table 2. Moulds and mycotoxins of world-wide importance

\begin{tabular}{|l|l|}
\hline Mould species & Mycotoxins produced \\
\hline $\begin{array}{l}\text { Aspergillus parasiticus } \\
\text { Aspergillus flavus } \\
\text { Fusarium sporotrichioides }\end{array}$ & $\begin{array}{l}\text { Aflatoxins B1, B2, G1, G2 } \\
\text { Aflatoxins B1, B2 } \\
\text { T-2 toxin }\end{array}$ \\
Fusarium graminearum & Deoxynivalenol (or nivalenol) \\
& Zearalenone \\
& Fumonisin B1 \\
Fusarium moniliforme (F. verticillioides) \\
$\begin{array}{l}\text { Penicillium verrucosum } \\
\text { Aspergillus ochraceus }\end{array}$
\end{tabular}$\quad$\begin{tabular}{l} 
Ochratoxin A \\
\hline
\end{tabular}

Adapted from: FAO ,2001.

\subsection{Factors influencing mould growth and mycotoxin production}

The fungal growth and the production of mycotoxins are greatly influenced by temperature, and water activity (Esteban et al., 2004; FAO, 2007). The optimal fungal growth and mycotoxin production conditions for some mycotoxins of worldwide importance, in particular with regard to (optimum) water activity and temperature is summarized in Table 3.

Moulds can grow over a wide range of temperatures and, in general, the rate of mould growth will decrease with decreasing temperature and available water. In grains, moulds utilize inter granular water vapor, the concentration of which is determined by the state of the equilibrium between free water within the grain (the grain moisture content) and water in the vapors phase immediately surrounding the granular particle(FAO ,2007).

Table 3.Growth and mycotoxin production conditions for moulds of world-wide importance

\begin{tabular}{|c|c|c|c|c|}
\hline Mould species & $\begin{array}{l}\text { Mycotoxins } \\
\text { produced }\end{array}$ & $\begin{array}{l}\text { Fungal growth } \\
\text { at water activity } \\
\text { (optimum) }\end{array}$ & $\begin{array}{l}\text { Fungal growth } \\
\text { at temperature } \\
\text { (optimum) }\end{array}$ & $\begin{array}{l}\text { Mycotoxin production: } \\
\text { water activity } \\
\text { temperature } \\
\text { (optimum) }\end{array}$ \\
\hline $\begin{array}{l}\text { Aspergillus } \\
\text { parasiticus }\end{array}$ & $\begin{array}{l}\text { Aflatoxins B1, } \\
\text { B2, G1, G2 }\end{array}$ & $\begin{array}{l}0.83->0.99 \\
(0.99)\end{array}$ & $\begin{array}{l}\text { unknown } \\
\left(30^{\circ} \mathrm{C}\right)\end{array}$ & $\begin{array}{l}\geq 0.87 \\
\text { unknown } \\
\left(28^{\circ} \mathrm{C}\right)\end{array}$ \\
\hline $\begin{array}{l}\text { Aspergillus } \\
\text { flavus }\end{array}$ & Aflatoxins B1, B2 & $\begin{array}{l}0.82->0.99 \\
(0.99)\end{array}$ & $10-43^{\circ} \mathrm{C}\left(30^{\circ} \mathrm{C}\right)$ & $\begin{array}{l}\text { High water activity } \\
15-37^{\circ} \mathrm{C} \\
\left(20-30^{\circ} \mathrm{C}\right)\end{array}$ \\
\hline $\begin{array}{l}\text { Fusarium } \\
\text { sporotrichioides }\end{array}$ & $\mathrm{T}-2$ toxin & $\begin{array}{l}0.88->0.99 \\
\text { (unknown) }\end{array}$ & $\begin{array}{l}2-35^{\circ} \mathrm{C} \\
\left(22.5-27.5^{\circ} \mathrm{C}\right)\end{array}$ & unknown \\
\hline $\begin{array}{l}\text { Fusarium } \\
\text { graminearum }\end{array}$ & $\begin{array}{l}\text { Deoxynivalenol } \\
\text { Zearalenone }\end{array}$ & $\begin{array}{l}0.90->0.99 \\
\text { (unknown) }\end{array}$ & $\begin{array}{l}\text { unknown } \\
\left(24-26^{\circ} \mathrm{C}\right)\end{array}$ & unknown \\
\hline $\begin{array}{l}\text { Fusarium } \\
\text { moniliforme } \\
\text { (verticillioides) }\end{array}$ & Fumonisin B1 & $\begin{array}{l}0.87->0.99 \\
\text { (unknown) }\end{array}$ & $\begin{array}{l}2.5-37^{\circ} \mathrm{C} \\
\left(22.5-27.5^{\circ} \mathrm{C}\right)\end{array}$ & unknown \\
\hline $\begin{array}{l}\text { Penicillium } \\
\text { verrucosum }\end{array}$ & Ochratoxin A & $\begin{array}{l}\geq 0.80 \\
\text { (unknown) }\end{array}$ & $\begin{array}{l}0-31^{\circ} \mathrm{C} \\
\text { (unknown) }\end{array}$ & $\begin{array}{l}\geq 0.86 \\
0-31^{\circ} \mathrm{C} \\
\text { (unknown) }\end{array}$ \\
\hline $\begin{array}{l}\text { Aspergillus } \\
\text { ochraceus }\end{array}$ & Ochratoxin A & $\begin{array}{l}\geq 0.79 \\
\text { (unknown) }\end{array}$ & $\begin{array}{l}8-37^{\circ} \mathrm{C} \\
\left(25-31^{\circ} \mathrm{C}\right)\end{array}$ & $\begin{array}{l}\text { unknown } \\
15-37^{\circ} \mathrm{C} \\
\left(25-28^{\circ} \mathrm{C}\right)\end{array}$ \\
\hline
\end{tabular}

Adapted from:RIVM, 2007. 


\subsection{Impact of mycotoxin}

\subsection{Economic Impacts}

Mycotoxins have an important economic impact because of the direct loss of products which are unfit for sale and the indirect costs of mitigation strategies (Anonymous, 2003). Mycotoxins have significant economic impacts in numerous crops, especially wheat, maize, peanuts and other nut crops, cottonseed, and coffee. The Food and Agriculture Organization has estimated that $25 \%$ of the world's crops are affected by mycotoxins each year, with annual losses of around 1 billion metric tons of foods and food products world wide (Schmale and Munkvold, 2011).Due to the EU regulatory limit, export of agricultural products particularly groundnut from African countries have dropped in recent years ( Otzuki et al., 2001).

2.4.2. Health impact

Human health impacts of mycotoxins are the most difficult to quantify. It is clear that mycotoxins affect human health, especially aflatoxins in developing countries. These effects are due to acute (single exposure) toxicoses and immune suppression by mycotoxins, as well as chronic (repeated exposure) effects (Schmale and Munkvold, 2011).

Due to their various toxic effects and good thermal stability, the presence of mycotoxins on foods and feeds is potentially hazardous to the health of both humans and animals (Fellinger, 2006; Barug et al., 2003 cited in Wagacha and Muthomi, 2008, p.4). In many regions of the world, dietary staples, especially cereal grains contain low levels of mycotoxins. The impact of regular low level intake of mycotoxins on human health is likely to be significant with a number of possible consequences including impaired growth and development, immune dysfunction and the disease consequences of alterations in DNA metabolism (Bryden, 2007).

Diseases in animals and human beings resulting from consumption of mycotoxins are called mycotoxicoses (Okello et al., 2010).Mycotoxicoses such as Ergotism, killed thousands of people in Europe in the last thousand years, alimentary toxic aleukia (ATA) killed many thousands of people in the USSR in the 1940s; stachybotryotoxicosis, killed tens of thousands of horses and cattle in the USSR in the 1930s; and aflatoxicosis, killed 100,000 young turkeys in England in 1960 and has caused death and disease in many other animals, and perhaps man as well. The 2004 outbreak of acute aflatoxicoses in Eastern Kenya was also one of the most severe of human aflatoxicoses in history where a total of 317 cases and 125 deaths were reported (Lewis et al., 2005).

\subsection{Mycotoxin management}

Mycotoxins primarily enter into the human and animal food chains through agricultural Products, mainly cereals, nuts and oilseeds or from products derived from them (IFST,2009).Strategies to address the food safety and economic issues employ both pre harvest and post harvest measures to reduce the risk of mycotoxin contamination in food and feed (Choudhary and Kumari, 2010).

Preharvest management of toxigenic risks is, ultimately, only half the battle (SP-IPM, 2009). Prevention through pre-harvest management is the best method for controlling mycotoxin contamination; however, should the contamination occur or persist after this phase, the hazards associated with the toxins must be managed through post-harvest procedures if the product is to be used for food and feed purposes(Schmale and Munkvold, 2011).Postharvest handling of grain determines the extent to which organisms are allowed to spread and produce mycotoxins, and this is the period during which the bulk of harmful substances are made (SP-IPM, 2009).

\subsection{Post harvest Prevention and control of mycotoxins}

In the post-harvest phase, storage and processing are the major areas where contamination can be prevented (Schmale and Munkvold, 2011). For post-harvest mycotoxin control prevention of conditions that favor fungal growth and subsequent toxin production needs to be considered, i.e. factors such as water activity of stored products, temperature, grain condition, gas composition of the intergranular air, microbial interactions, and presence of chemical or biological preservatives (Shapira and Paster, 2004 cited in Binder, 2007, p.159).

Mycotoxin researchers have proposed many solutions against mycotoxin production in the post harvest food chain of durable crops. However all mycotoxin management methods used in developed countries cannot realistically be used in developing countries because of the characteristics of the food systems and the technological infrastructure in those countries resulting in uncontrolled mycotoxin levels in these situations (Wagacha and Muthomi, 2008).Of all some of mycotoxin management strategies, which may be applicable in developing countries, are highlighted as follows.

\subsubsection{Early Harvesting}

Harvest is the first stage in the production chain where moisture content becomes the most important parameter in terms of the management and protection of the crop. It also marks a shift from problems caused by plant pathogenic fungi, i.e. the Fusaria, to problems caused by storage fungi (Aldred and Magan, 2004).

Field crops should be harvested in timely manner to reduce moisture or water activity level to a point where mycotoxin formation will not occur and Mechanical damage of seeds should be kept to a minimum during this phase to reduce contamination (Choudhary and Kumari, 2010). According to (Kendra, 2009) early harvest 
followed by mechanical dry-down results in lower mycotoxin levels.

\subsubsection{Sorting}

Sorting out of physically damaged and infected grains from the apparently healthy ones is an efficient and feasible method of reducing mycotoxin contamination (Bankole and Adebanjo, 2003).It is the most effective and easiest processing method for small-scale farmers. Broken grains, which are much more prone to molding, and very moldy grains, which display obvious visible signs, can easily be removed. Maize may be sorted by the cob, removing both insect-damaged cobs and those with an incomplete husk. The reduction in total mycotoxin load from such a process can be significant, as the distribution of toxins in grain tends to be concentrated in a small percentage of seeds (SP-IPM, 2009). According to (Park, 2002)which is reviewed by (Bullerman and Bianchini,2007) Physical cleaning, where mold-damaged kernels, seeds or nuts are removed from the intact commodity, may result in 40$80 \%$ reduction of aflatoxins. While sorting, and cleaning may reduce mycotoxin concentrations in commodities, these operations may not completely remove all of the contamination. The initial condition of the grain, or commodity, and extent of the contamination will have an effect on cleaning efficiency (Bullerman and Bianchini, 2007).

2.6.3. Proper Drying

For most of the agricultural products affected by mycotoxins, post-harvest drying is one of the key elements of mycotoxin management plan. Fungal growth and mycotoxin production can be prevented when the moisture content of the product is held below a critical level (Schmale and Munkvold, 2011). If crops are harvested at an appropriate time and thoroughly dried-usually in the sun, in the developing world-mycotoxin production will cease (SP-IPM, 2009). When the maize cob, sorghum head, cowpea pod and groundnut pod have begun to dry in the field it is essential to dry them down to safe moisture content as quickly as possible, and to do so with as much care as is practicable (FAO, 2007). The general recommendation is that harvested commodities should be dried as quickly as possible to safe moisture levels of $10-13 \%$ for cereals (Hell and Mutegi, 2011). The study of (CairnsFuller et al., 2005) showed that approximately 17-18\% moisture content (ca. $0.80-0.83 \mathrm{aw}$ ) is the limit for any potential growth or OTA production in wheat grain. Thus, it is essential that grain is dried to lower moisture content as quickly as possible regardless of the drying system employed. There are several technologies to increase the efficacy of grain drying and reduce the risk of toxin contamination even under low input conditions. These include the use of drying platforms, drying outside the field and drying on mats (Hell et al., 2008 cited in Hell and Mutegi, 2011, p.4).

\subsubsection{Storage management}

Proper storage is important, and best policies for minimizing mycotoxins are congruent with good storage practice in general (SP-IPM, 2009).In the post-harvest phase, storage is one of the major areas where contamination can be prevented (Parket al., 1999). Avoiding mycotoxin accumulation in stored grains and oilseeds depends primarily on moisture control. If the product is too dry to allow fungal growth and it is kept dry, no further deterioration will occur. However, if there is insect or rodent activity, moisture migration, condensation, or water leaks, fungal growth that could lead to mycotoxin contamination will occur (Anonymous, 2003).

Clearing the remains of previous harvests and destroying infested crop residues are basic sanitary measures against storage deterioration. Cleaning of stores before loading in the new harvests was correlated to reduced aflatoxin levels (Hell et al., 2000).

Smoking is an efficient method of reducing moisture content and protecting maize against infestation by fungi. The efficacy of smoking in protecting against insect infestation was found to be high. About 4 to $12 \%$ of farmers in the various ecological zones in Nigeria used smoke to preserve their grains, and this practice was found to be correlated with lower aflatoxin levels in farmers' stores (Udoh et al., 2000).

\subsubsection{Detoxification}

Though prevention is the best control strategy, mycotoxin contamination will still sometimes occur. However, post harvest control and decontamination procedures represent important tools in avoiding exposure to mycotoxins. Detoxification of contaminated products can be achieved by thermal or chemical means. But it is one of the least preferred approaches to managing mycotoxins, due to the expense and the limitations sometimes placed on the use of decontaminated grain (Schmale and Munkvold, 2011).

Thermal inactivation

Thermal inactivation of mycotoxins usually is implemented as a stage in food or industrial processing (Schmale and Munkvold, 2011). Most mycotoxins are relatively heat stable, and it can be difficult to significantly reduce mycotoxin levels while maintaining product quality (Schmale and Munkvold, 2011). Heat treatments have shown that AF degradation is time and temperature dependent and effective treatments result in an inedible product (Yazdanpanah et al., 2005).

Chemical Detoxification

Various chemical methods have been developed with some success in breaking down mycotoxins in postharvest products. Among the chemical compounds tested in feeds, propionic acid, sodium propionate, benzoic acid and ammonia were the best anti-fungal compounds, followed by urea and citric acid (Gowda et al., 2004). The most 
well-known approach is the use of ammonia gas or ammonium sulfate to reduce aflatoxin levels in maize. This is a widely accepted practice internationally (Schmale and Munkvold, 2011). The chemical inactivation of aflatoxins is widely practiced on an industrial scale, with ammonia being the agent favored by the American cottonseed, peanut,and corn industries. Such treatment, however, leaves the product suitable only for animal feed, and greatly reduces palatability even for this purpose (SP-IPM, 2009)

Chemical inactivation of aflatoxin B1 (AFB1) and aflatoxin B2 (AFB2) in maize grain by means of $1 \mathrm{~N}$ aqueous citric acid was also confirmed and showed that aflatoxins in the maize grain, with an initial concentration of $29 \mathrm{ng} / \mathrm{g}$, were completely degraded, and $96.7 \%$ degradation occurred in maize contaminated with $93 \mathrm{ng} / \mathrm{g}$ when treated with the aqueous citric acid (M e $\mathrm{n} d$ e $\mathrm{z}$ et al., 2005).

Another strategy for safer animal feed is the use of clay mineral supplements such as NovaSil a common anti caking agent that is also known to bind with aflatoxins in the gastrointestinal tract. A similar approach was tested for humans in Ghana by the Peanut Collaborative Research Support Program and was found effective in reducing absorption of aflatoxins and its attendant health impact. This is a promising technology that may be of value in aflatoxin-endemic areas (SP-IPM, 2009)

Table 4. Purpose, status and application of harvest and post-harvest procedures for removing mycotoxins from human foods and animal feeds

\begin{tabular}{|c|c|c|c|}
\hline Procedure & Mycotoxins & Commodities & Purpose/status/application \\
\hline \multicolumn{4}{|l|}{ Harvesting operations } \\
\hline $\begin{array}{l}\text { Timeliness of clean-up and } \\
\text { drying of commodities }\end{array}$ & Aflatoxins & Maize & $\begin{array}{l}\text { Reduce exposure to toxigenic moulds and } \\
\text { moisture levels in commodities }\end{array}$ \\
\hline \multicolumn{4}{|l|}{ Post-harvest procedures } \\
\hline $\begin{array}{l}\text { Physical separation of } \\
\text { damaged, immature and } \\
\text { mould-infested kernels, } \\
\text { nuts, seeds, etc. }\end{array}$ & $\begin{array}{l}\text { Aflatoxins, } \\
\text { fumonisins }\end{array}$ & Maize, peanuts & $\begin{array}{l}\text { Effective in reducing mycotoxin levels in } \\
\text { final product; mycotoxins can diffuse into } \\
\text { apparently good commodities }\end{array}$ \\
\hline Thermal processing & $\begin{array}{l}\text { Aspergillus, } \\
\text { Fusarium } \\
\text { toxins }\end{array}$ & $\begin{array}{l}\text { Maize, cereal } \\
\text { grains, }\end{array}$ & $\begin{array}{l}\text { However, many mycotoxins are thermally } \\
\text { stable }\end{array}$ \\
\hline $\begin{array}{l}\text { Chemical inactivation by } \\
\text { ammoniation }\end{array}$ & $\begin{array}{l}\text { Aflatoxins, } \\
\text { fumonisins }\end{array}$ & $\begin{array}{l}\text { Maize, peanuts, } \\
\text { cottonseed }\end{array}$ & Feed mill and farm applications \\
\hline
\end{tabular}

Adapted from:Lopez-Garcia,Park, and Phillips ,1999.

2.6.6. HACCP as means of mycotoxin control

Mycotoxins are highly undesirable substances that should not be present in food and for which a zero tolerance would be ideal. However, even good agricultural, storage and processing practices cannot completely prevent contamination; and it is impossible to achieve a truly mycotoxin-free food chain (Galvano et al., 2005 cited in Degirmencioglu et al., 2005, p.5). The risk of contamination by mycotoxins is an important food safety concern for grains and other field crops ( Degirmencioglu et al., 2005) and Knowledge of the key critical control points during the harvesting, drying, and storage stages of the cereal production chain is essential for the development of effective pre- and postharvest prevention strategies.

HACCP or Hazard Analysis Critical Control Point is a common approach used in food safety programs (Schmale and Munkvold, 2011).It is a system that identifies, evaluates and controls hazards which are significant for food safety (FAO/ IAEA, 2001). This approach has been recommended and implemented in relation to preventing mycotoxin contamination of food products (Schmale and Munkvold, 2011). Possible stages in application of the HACCP principle to agricultural commodities, food products at harvest and post harvest stages are listed on (table 5).

HACCP programs have been established for mycotoxin control in various crops including maize, coffee, nut crops, and apples in a number of different countries. The approach is well-suited for mycotoxins because it can reduce the need for costly end-point testing for quality control (Schmale and Munkvold, 2011). 
Table 5.Possible stages in application of the HACCP principle to agricultural commodities, food products at harvest and post harvest stages

\begin{tabular}{|c|c|c|c|}
\hline Stage & Commodity & Hazard & Corrective action \\
\hline Harvesting & $\begin{array}{lr}\text { Cereal grains, } \\
\text { oilseeds, nuts, } \\
\text { fruits }\end{array}$ & $\begin{array}{l}\text { Increase in } \\
\text { mycotoxin formation }\end{array}$ & $\begin{array}{l}\text { Harvest at appropriate time } \\
\text { Maintain at lower temperature, if } \\
\text { possible } \\
\text { Remove extraneous material } \\
\text { Dry rapidly to below } 10 \% \text { moisture }\end{array}$ \\
\hline $\begin{array}{l}\text { Post-harvest } \\
\text { storage }\end{array}$ & $\begin{array}{l}\text { Cereal grains, } \\
\text { oilseeds, nuts }\end{array}$ & $\begin{array}{lr}\text { Increase } & \text { and/or } \\
\text { occurrence } & \text { of } \\
\text { mycotoxin } & \\
\end{array}$ & $\begin{array}{l}\text { Protect stored product from moisture, } \\
\text { insects, environmental factors, etc. } \\
\text { Store product on dry clean surface }\end{array}$ \\
\hline $\begin{array}{l}\text { Post-harvest, } \\
\text { processing } \\
\text { manufacturing }\end{array}$ & $\begin{array}{l}\text { Cereal grains, } \\
\text { oilseeds, nuts, }\end{array}$ & $\begin{array}{l}\text { Mycotoxin carryover } \\
\text { or contamination }\end{array}$ & $\begin{array}{l}\text { Test all ingredients added } \\
\text { Monitor processing/manufacturing } \\
\text { operation to maintain high-quality } \\
\text { product } \\
\text { Follow good manufacturing practices }\end{array}$ \\
\hline
\end{tabular}

Adapted from:Park,Njapau ,and Boutrif ,1999.

\section{Conclusions and recommendations}

Mycotoxins are the main food safety hazard associated with cereals and their products pulses and oilseeds. They affect the agricultural economies of many countries, interfere or even prevent trade, reduce animal and animal product production and affect human health. To reduce these problems in post harvest food chain of durable crops; post harvest management strategies that lowers fungal contamination and consequently, reduce the risk of post harvest contamination by mycotoxin such as: early harvesting, proper dying, sorting of damaged grains from undamaged, and storage management are recommended, and application of the HACCP principle to agricultural commodities and food products at harvest and post harvest stages and thermal, and chemical detoxification should be implemented in the post harvest food chain of durable crops and researches that focus on technologies that minimize mycotoxin contamination are also important.

\section{References}

Aldred, D.and Magan, N., 2004. The use of HACCP in the control of mycotoxins: the case of cereals. In: N. Magan and M.Olsen, (ed.), 2004. Mycotoxins in food: detection and control. Wood head Publishing Limited, pp.139173.

[Online] Available at: http://fars.itvhe.ac.ir/_fars/Documents/7b2ad138-c455-4b84-b21f-5f6930439424.pdf [Accessed on 10 October 2011].

Anonymous, 2003. Mycotoxins: Risks in plant, animal, and human systems. Council for Agricultural Science and Technology. CAST Task Force Report No. 139. Ames, Iowa, USA.

[Online] Available at: http://www.trilogylab.com/pdf/Mycotoxin_CAST_Report.pdf [Accessed on 10 October 2011].

Bankole, S.A.and Adebanjo, A., 2003. Mycotoxins in food in West Africa: current situation and possibilities of controlling it. African Journal of Biotechnology, 2 (9):254-263.

[Online] Available at: http://www.academicjournals.org/AJB [Accessed on 15 september2011].

Bryden, L.W., 2007.Mycotoxins in the food chain: human health implications. Asia Pacific Journal of Clinical Nutrition, 16 (Suppl .1):95-101.

[Online] Available at:apjcn.nhri.org.tw/server/apjcn/...1/WayneBryden (95-101).pdf [Accessed on 25 September 2011].

Binder, E.M., 2007.Managing the risk of mycotoxins in modern feed production. Animal Feed Science and Technology, 133:149-166.

[Online] Available at: linkinghub.e lsevier. Com / retrieve/pii/S 0377840106003105 [Accessed on 25 July 2011].

Bullerman, L.B. and Bianchini, A., 2007.Stability of mycotoxins during food processing. International Journal of Food Microbiology, 119: 140-146.

Cairns-Fuller,V., Aldred, D.and Magan, N., 2005. Water, temperature and gas composition interactions affect growth and ochratoxin A production by isolates of Penicillium verrucosum on wheat grain. Journal of Applied Microbiology, 99:1215-1221.

Cardwell, K.F., Desjardins, A., Henry, S.H., Munkvold, G. and Robens, J., 2001. Mycotoxins: the Cost of Achieving Food Security and Food Quality. [Online] Available at: http://www.apsnet.org/publications/apsnetfeatures/Pages/Mycotoxins.aspx [Accessed on 25 September 2011].

Choudhary, A.K. and Kumari, P., 2010. Management of mycotoxin contamination in pre harvest and post harvest 
crops: Present status and future prospects. Journal of Phytology, 2(7):37-52.[Online]Available at: http://journal-phytology.com/article/viewFile/4472/2206 [Accessed on 23 July 2011].

Degirmencioglu, N., Eseceli, H., Çokal, Y. and Bilgiç, M., 2005.From safety feed to safety food: the application of HACCP in mycotoxin control. Archiva Zootechnica, 8.

[Online] Available at: http://www.ibna.ro/arhiva/AZ\%208/AZ\%208_02\%20Nurcan.pdf

[Accessed on 8 September 2011].

Dohlman, E., 2003. Mycotoxin Hazards and Regulations Impacts on Food and Animal Feed Crop Trade. In: J.C Buzby (ed.), 2003.International Trade and Food Safety/ AER-828.Economic Research Service/USDA.

[Online]Available at: http://www.ers.usda.gov/publications/aer828/aer828h.pdf [Accessed on 11August 2011].

Esteban, A., Abarca, M. L., Bragulat, M. R.and Cabañes,F. J.,2004.Effects of temperature and incubation time on production of ochratoxin A by black aspergilli .Research in Microbiology ,155:861-866.

FAO/ IAEA, 2001 .Manual on the Application of the HACCP System in Mycotoxin Prevention and Control.FAO food and nutrition paper No. 73. Rome, Italy.

[Online]Available at: http://www.fao.org/docrep/005/y1390e/y1390e00.htm[Accessed on 20 June 2011].

FAO, 2007. On-farm mycotoxin control in food and feed grain. Training manual on good practices for animal feed and livestock. Rome, Italy:

[Online] Available at: ftp://ftp.fao.org/docrep/fao/010/a1416e/a1416e00.pdf [Accessed on 10 October 2011].

Gowda, N., Malathi, V.and Suganthi, R., 2004. Effect of some chemical and herbal compounds on growth of Aspergillus parasiticus and aflatoxin production. Animal Feed Science and Technology, 116(3-4): 281-291.

Hell, K., Cardwell, K.F., Setamou, M.and Poehling, H.M., 2000. The influence of storage practices on aflatoxin contamination in maize in four agro ecological zones of Benin, West Africa. Journal of Stored Products research, 36:365-382.

Hell, K., Gnonlonfin, B.G.J., Kodjogbe, G., Lamboni, Y. and Abdourhamane, I.K., 2009. Mycoflora and occuuerence of aflatoxin in dried vegetables in Benin, Mali and Togo, West Africa. International Journal of Food Microbiology, 135 (2): 99-104.

Hell, K., Mutegi, C.and Fandohan, P., 2010.Aflatoxin control and prevention strategies in maize for Sub-Saharan Africa.10th International Working Conference on Stored Product Protection.Julius-KühnArchiv, 425.

[Online]Available at: pub.jki.bund.de/index.php/JKA/article/download/545/1260 [Accessed on 30 September 2011].

Hell, K and Mutegi, C.2011.Aflatoxin control and prevention strategies in key crops of Sub-Saharan Africa. African Journal of Microbiology Research, 5(5):459-466.

[Online] Available at: http://www.academicjournals.org/ajmr [Accessed on 30 September 2011].

IFST, 2009.Mycotoxins [pdf], Available at: www.ifst.org [accessed on 30 September 2011].

Kaaya, A.N., Warren, H.L., Kyamanywa, S. and Kyamuhan, W., 2005. The effect of delayed harvest on moisture content, insect damage, moulds and aflatoxin contamination of maize in Mayuge district of Uganda. Journal of the Science of Food and Agriculture, 85: 2595-2599.

Kendra, D. F, 2009. The Impact of Crop, Pest and Agricultural Management Practices on Mycotoxin Contamination of Field Crops.OECD Conference challenges for agricultural research, Prague, Czech Republic.

[Online] Available at: http://www.oecd.org/dataoecd/14/32/42582862.pdf [Accessed on 29 September 2011].

Lewis, L., Onsongo, M., Njapau, H., Schurz-Rogers, H., Luber, G.and Kieszak, S., 2005. Aflatoxin Contamination of Commercial Maize Products during an Outbreak of Acute Aflatoxicosis in Eastern and Central Kenya. Environ Health Perspective, 113:1763-1767. [Online] Available at: http://www.ncbi.nlm.nih.gov/pmc/articles/PMC1314917/?tool=pubme [Accessed on 22 September 2011].

Lopez-Garcia, R., Park, D.L.and Phillips, T.D., 1999. Integrated mycotoxin management systems. In: Food, nutrition and agriculture.FAO corporate repository. FNA/ANA 23. Rome, Italy.

[Online] Available at: http://www.fao.org/docrep/X2100T/X2100T00.htm. [Accessed on 22 August 2011].

Majiwa, P., Odera, M., Muchiri, N., Omanya, G.and Werehire, P. (ed.), 2007.Small Group Meeting on Mycotoxin Control in Food Grains. Nairobi, Kenya: African Agricultural Technology Foundation.

[Online]Available at: http://www.aatf-africa.org/userfiles/Mycotoxin.pdf [Accsseced on 12August 2011]

Me'ndez-Albores,A.,Ara'mbula-Villa,G.,Loarca-Piña,M.G.F.,Castaño-Tostado,E.and Moreno-Martı'nez, E.,2005.Safety and efficacy evaluation of aqueous citric acid to degrade B-aflatoxins in maize.Food and Chemical Toxicology,43(2): 233-238.

Miller, J.D., 1995. Mycotoxins. In: K.F. Cardwell (Ed.), 1996. Proceedings of the Workshop on Mycotoxins in Foods in Africa. November 6-10, 1995, Cotonou, Benin.

[Online]

at: http://www.cd3wd.com/cd3wd_40/INPHO/VLIBRARY/NEW_ELSE/X5422E/EN/X5422E00.HTM [Accessed on 8 October 2011].

Negedu, A., Ameh, J.B., Umoh, V.J. and Atawodi, S.E. ,2010.Occurrence of Mycotoxins in Aspergillus Tamarii- 
infected Wild Castor Seeds in Storage. Continental Journal of Microbiology, 4: 37 - 43.

[Online]Available at: http://www.wiloludjournal.com [Accessed on 3 September 2011].

Okello, D. K., Kaaya, A. N., Bisikwa, J., Were, M.and Oloka, H. K., 2010. Management of Aflatoxins in Groundnuts: A manual for Farmers, Processors, Traders and Consumers in Uganda. National Agricultural Research Organisation, Entebbe.

[Online]Available at: http://www.naro.go.ug/Information/narodocuments/groundnut $\% 20$ aflatotoxin $\% 20 \mathrm{mgt} \% 20$ manual $\% 20$ Ugan da.pdf [Accessed on 22 September 2011].

Otzuki, T., Wilson, J.S. and Sewadeh, M., 2001. What price precaution? European harmonization of aflatoxin regulations and African groundnut exports. European Review of Agricultural Economics, 28: 263-283.

Park, D.L., Njapau, H.and Boutrif, E., 1999.Minimizing risks posed by mycotoxins utilizing the HACCP concept In: Food, nutrition and agriculture.FAO corporate repository. FNA/ANA 23.Rome, Italy.

[Online] Available at: http://www.fao.org/docrep/X2100T/X2100T00.htm [Accessed on 7 October 2011]

Pestka, J.J., 2007. Deoxynivalenol: Toxicity, mechanisms and animal health risks. Animal Feed Science and Technology, 137(3-4): 283-298.

Reyneri, A., 2006. The role of climatic condition on micotoxin production in cereal. Veterinary Research Communications, 30(Suppl. 1), 87-92.

[Online] Available at: http://www.springerlink.com/content/q3681418785np74l/fulltext.pdf [Accessed on 8 October 2011].

RIVM, 2007.Information sources for the detection of emerging mycotoxin risks.

[Online] Available at: http://www.elika.net/datos/articulos/Archivo_EU250/RIVM_Micotox07.pdf

[Accessed on 8 October 2011].

Schmale, G.D.and Munkvold, P.G., 2011.Mycotoxins in Crops: A Threat to Human and Domestic Animal Health. The American Phytopathological Society.

[Online]Available at: http://www.apsnet.org/edcenter/intropp/topics/Mycotoxins/Pages/default.aspx

[Accessed on 15 July 2011].

Sobrova,P.,Adam,V.,Vasatkova,A.,Beklova,M.,Zeman,L.andKizek,R.,2010. Deoxynivalenol and its toxicity. Interdisciplinary Toxicology, 3 (3): 94-99.

[Online] Available at: http://www.ncbi.nlm.nih.gov/pmc/articles/PMC2984136/pdf/ITX-3-094.pdf [Accessed on 28 September 2011].

SP-IPM, 2009.Advances in Preventing and Managing Contaminants in Foods, Feeds, and the Environment. IPM Research Brief No. 7.SP-IPM Secretariat, International Institute of Tropical Agriculture (IITA), Ibadan, Nigeria. $40 \mathrm{pp}$.

[Online]

Available

at:

http://www.spipm.cgiar.org/c/document_library/get_file?p_l_id=17830\&folderId=18484\&name=DLFE146.pdf [Accessed on 9 October 2011].

Turner, P.C., Moore, S.E., Hall, A.J., Prentice, A.M. and Wild, C.P., 2003. Modification of immune function through exposure to dietary aflatoxin in Gambian children. Environmental Health Perspectives, 111:217-220.

Udoh, J.M., Cardwell, K.F.and Ikotun, T., 2000. Storage structures and aflatoxin content of maize in five agro ecological zones of Nigeria. Journal of Stored Products Research, 36(2): 187-201.

Varga, J., Kocsubé, S., Péteri, Z., Vágvölgyi, C. and Tóth, B., 2010.Chemical, Physical and Biological Approaches to Prevent Ochratoxin Induced Toxicoses in Humans and Animals. Toxins, 2(7):1718-1750.

Wagacha, J.M. and Muthomi, J.W., 2008.Mycotoxin problem in Africa: Current status, implications to food safety and health and possible management strategies. International Journal of Food Microbiology, 124 (1): 1-12.

Yazdanpanah, H., Mohammadi, T., Abouhossain, G. and Cheraghali, A.M., 2005. Effect of roasting on degradation of Aflatoxins in contaminated pistachio nuts. In: Food and Chemical Toxicology, 43(7):11351139 . 